\title{
Effects of Climate and the Urban Heat Island Effect on Urban Tree Growth in Houston
}

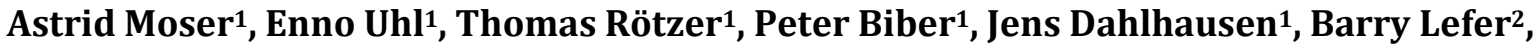 \\ Hans Pretzsch ${ }^{1}$ \\ ${ }^{1}$ Chair of Forest Growth and Yield Science, Center of Life and Food Sciences Weihenstephan, Technical University Munich, \\ Freising, Germany \\ ${ }^{2}$ NASA Headquarters, Earth Science Division, Washington DC, USA \\ Email: astrid.moser@lrz.tum.de
}

How to cite this paper: Moser, A., Uhl, E., Rötzer, T., Biber, P., Dahlhausen, J., Lefer, B., \& Pretzsch, H. (2017). Effects of Climate and the Urban Heat Island Effect on Urban Tree Growth in Houston. Open Journal of Forestry, 7, 428-445.

https://doi.org/10.4236/ojf.2017.74026

Received: July 18, 2017

Accepted: October 23, 2017

Published: October 26, 2017

Copyright (c) 2017 by authors and Scientific Research Publishing Inc. This work is licensed under the Creative Commons Attribution International License (CC BY 4.0).

http://creativecommons.org/licenses/by/4.0/

\begin{abstract}
The growing conditions of urban trees differ substantially from forest sites and are mainly characterized by small planting pits with less water, nutrient and aeration availability, high temperatures and radiation inputs as well as pollution and soil compaction. Especially, global warming can amplify the negative effects of urban microclimates on tree growth, health and well-being of citizens. To quantify the growth of urban trees influenced by the urban climate, ten urban tree species in four climate zones were assessed in an overarching worldwide dendrochronological study. The focus of this analysis was the species water oak (Quercus nigra L.) in Houston, Texas, USA. Similar to the overall growth trend, we found in urban trees, water oaks displayed an accelerated growth during the last decades. Moreover, water oaks in the city center grew better than the water oaks growing in the rural surroundings of Houston, though this trend was reversed with high age. Growth habitat (urban, suburban, rural and forest) significantly affected tree growth $(p<0.001)$ with urban trees growing faster than rural growing trees and forest trees, though a younger age of urban trees might influence the found growth patterns. Growing site in terms of cardinal direction did not markedly influence tree growth, which was more influenced by the prevalent climatic conditions of Houston and the urban climate. Higher temperatures, an extended growing season and eutrophication can cause an accelerated growth of trees in urban regions across, across all climatic zones. However, an accelerated growth rate can have negative consequences like quicker ageing and tree death resulting in higher costs for new plantings and tree management as well as the decrease in ecosystem services due to a lack of old trees providing greatest benefits for mitigating the negative effects of the urban climate.
\end{abstract}




\section{Keywords}

Climate Change, Growth Trends, Heat Island Effect, Quercus nigra, Tree Ring Analyses

\section{Introduction}

Urban tree growth is limited by many factors diverging from forest stands such as soil compaction (Bartens et al., 2008; Bühler et al., 2007; Gregory et al., 2006), reduced soil aeration, limited nutrient and water availability (Morgenroth \& Buchan, 2009; Rahman et al., 2013), shading through buildings, high nitrogen inputs through pollutants and dog urine as well as vandalism (Cekstere et al., 2008; Petersen \& Eckstein, 1988). Climate change is expected to amplify the prevalent conditions of the city climate, the so-called urban heat island effect (Coburn, 2009; Oke, 1987; Tan et al., 2010). Affected by newly introduced pests and diseases, the vitality and growth of many common urban tree species adapted to current climate will probably decrease (Sjöman et al., 2015; Tubby \& Webber, 2010). Since the expected life-span of urban trees is comparably short (Roman \& Scatena, 2011)-ranging from very short 13 years for probably unestablished street trees in the US (Skiera \& Moll, 1992) to 30 years up to 73 years for street trees depending on the tree species (Richards, 1979), a reduced life expectancy due to climate change will worsen the health situation of tree species in cities. Moreover, the decrease in health and life-span will lead to a faster need of replacement and hence higher costs for tree management and administration (Soares et al., 2011).

Several recent studies quantify the consequences of climate change on common urban tree species worldwide and how newly introduced species from other climate regions will perform as urban trees (Böll et al., 2014; City of London, 2014; Pretzsch et al., 2015b). Higher tree species diversity in cities will likely increase urban biodiversity and the resistance of the whole urban tree stand of a city to pests and diseases (Raupp et al., 2006; Tubby \& Webber, 2010), and provide a wider range of aesthetic features and ecosystem services to mitigate the consequences of global warming and worsening climate scenarios in city centers (Bassuk et al., 2009; Cregg \& Dix, 2001; Sjöman et al., 2012). Surprisingly, contrary positive effects despite all the mentioned negative consequences of global warming on tree growth have been found as well (Fang et al., 2014; Kauppi et al., 2014). In their study about forest tree growth, Pretzsch et al. (2014) highlighted a faster growth of forests since the last decades. Global warming and higher immissions of nutrients and pollutions accelerated tree growth.

In addition to the results on forest growth, a worldwide overarching study on the effects of different urban microclimates on urban tree growth found similar results (Pretzsch et al., 2015a; Pretzsch et al., 2017). In the course of this study a total of 1383 urban trees were dendrochronologically sampled in ten metropo- 
lises worldwide, covering boreal (Sapporo, Japan; Prince George, Canada), temperate (Paris, France; Munich, Berlin, Germany), Mediterranean (Cape Town, South Africa; Santiago de Chile, Chile), and subtropical (Hanoi, Vietnam; Houston, USA; Brisbane, Australia) climate conditions. The sampled trees of a defined species per city were selected from the city center to the suburban and rural area, following different trajectories from the city center. The following species were covered by the study (Abies sachalinensis Mast. (Sachalin fir), Picea glauca (Moench) Voss (white spruce), Tilia cordata Mill. (small-leaved lime), Aesculus hippocastanum L. (horse-chestnut), Platanus x hispanica Münchh. (London plane), Robinia pseudoacacia L. (black locust tree), Quercus robur L. (English oak), Khaya senegalensis (Desr.) A. Juss. (African mahogany), Araucaria cunninghamii Aiton ex. D. Don) (hoop pine), Quercus nigra L. (water oak). Dating back more than 100 years, the tree ring chronologies reflect the effect of global climate change and the urban heat island on urban tree growth worldwide.

Tropical and subtropical climate regions will be affected by climate change most severely. The predicted climate changes due to climatic conditions will directly influence the living conditions of the urban populations and can be detrimental for the life quality of humans, especially risk groups and also all other biota (Santamouris et al., 2011). Houston, Texas, USA with its subtropical climate is a typical example for a city which will probably suffer tremendously of frequent heat waves, dry periods and heavy rain events as well as hurricanes (IPCC, 2013; Mueller et al., 2005). During the past year, temperatures in Houston, Texas have risen by $3.3^{\circ} \mathrm{F}$ and exceed on some days temperatures of $100^{\circ} \mathrm{F}$ (around $37.7^{\circ} \mathrm{C}$ ), as happened during the drought year 2011 (Shafer et al., 2014). By the year 2100 , climate predictions expect around 70 days of temperatures over $100^{\circ} \mathrm{F}$ in Houston (Wang, 2014). Together with increased temperatures, Houston is suffering frequently of flooding such as the flooding event in 2015. Caused by to climate change, extreme and unpredictable rainfall events will occur more often (Climate Central, 2015).

Urban green and in particular urban trees will have a key function in adapting cities to climate change since they can ameliorate the mentioned negative city climate (Dimoudi \& Nikolopoulou, 2003; Dobbs et al., 2014) by providing evaporative cooling and shading (Akbari et al., 2001; Rahman et al., 2017), air pollution removal (Escobedo \& Nowak, 2009; Pretzsch et al., 2015a), wind and noise buffering, run-off mitigation (Bolund \& Hunhammar, 1999; Gómez-Baggethun \& Barton, 2013) and recreational services (Gómez-Baggethun \& Barton, 2013; Tyrväinen et al., 2005). Water oak (Quercus nigra L.) is a very common, semi-evergreen urban tree species, which has been planted frequently in central and south-eastern US states due to its suitable features as a street and shade tree in urban areas. It is a typical species of humid climate regions and can grow well in subtropical areas. Its water demanding behavior, though, will make it not very suitable for future climate scenarios with even drier and warmer conditions in 
urban areas (Leistikow, 2013). In this study, the growth of water oak under past and current climate will be studied to reveal reaction patterns to extreme climate event as well as to analyze possible future growth reactions under climate change scenarios of water oak in Houston, Texas. Therefore the research questions of this study are:

1) How was the diameter growth of water oak in the past until today in the urban region of Houston?

2) Can overall growth trends due to climate change be identified for water oak in the urban region of Houston?

3) Are there differences in the growth of water oak related to different urban zones in the city of Houston or in relation to the distance to the city center?

4) Is the growth of water oak affected by the grade of soil sealing?

\section{Material and Methods}

\subsection{Climate of Houston}

The climate of Houston (Figure 1) is characterized as subtropical with warm summer month and fair amounts of rainfall throughout the year. In winter from May to September, the temperature is mild with high precipitation. The yearly mean temperature is $21^{\circ} \mathrm{C}$ and the yearly average amount of precipitation is $1264 \mathrm{~mm}$.

Climate data for Houston were provided by the National Climatic Data Center (NCDC \& NOAA, 2014). For the greater area of Houston, five weather stations are available, the Houston William P Hobby Airport (1940-2014) in the southeast, Houston Intercontinental Airport (1969-2014) in northern direction, Houston Weather Bureau City (1940-1990) in the city center, the Conroe Montgomery County Airport (1940-2014) and Conroe (1998-2014) both located further away in northern direction close to the Conroe forest site.

\subsection{Data Collection}

Throughout the city, 183 water oak trees were chosen for data collection. Data

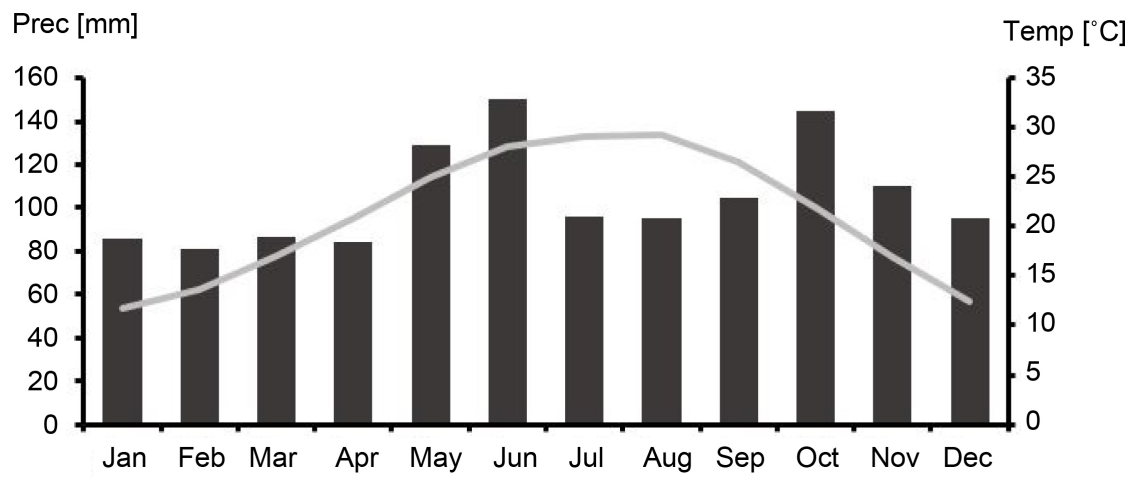

Figure 1. Monthly temperature (Temp, grey line) and precipitation (Prec, black bars) in Houston, Texas from 1981-2010. Values were derived by averaging climate data of all weather stations of the Houston area. 
collection was conducted along three transects through the city, providing a gradient which considers factors such as air pollution, temperature and urbanity (Figure 2). The grade of urbanity was divided into the categories urban, suburban, rural and forest depending on the growing site of the sampled water oaks. The trees were categorized based on their distance to the city center: trees in a distance up to $4.5 \mathrm{~km}$ were classified as urban, in a distance to $9.5 \mathrm{~km}$ to the city center water oak was sampled as suburban and above $9.5 \mathrm{~km}$ trees were classified as rural. Forest trees were located at the WG Jones State Forest in approx. $60 \mathrm{~km}$ distance to Houston.

Prior to increment core collection, tree structural data and prevalent site conditions were recorded, including diameter at breast height $1.3 \mathrm{~m}(\mathrm{dbh})$, tree height $(\mathrm{h})$, height to the crown base (cb), crown radii in eight cardinal directions (N, NE, E, SE, S, SW, W, NW), tree position (coordinates and altitude), site condition, tree vitality, open surface area of the unpaved area around the tree. Based on these data, mean crown radius $(c r)$ and crown projection area (cpa) were calculated as following

$$
\begin{gathered}
c r=\sqrt{\left(r_{N}^{2}+r_{N E}^{2}+\cdots+r_{N W}^{2}\right) / 8} \\
c p a=c r^{2} * \pi
\end{gathered}
$$

Following increment core collection was conducted at each tree with extraction of two cores in opposing directions $(\mathrm{N}, \mathrm{E})$ at a height of $1.3 \mathrm{~m}$ aimed at the center of the tree. The increment corer was $5 \mathrm{~mm}$ in diameter of Haglöf (Sweden).

\subsection{Core and Data Processing}

The obtained cores were further processed by gluing on wooden racks and sanded with higher grit to ensure highest visibility of the cross-sectional area consistently for every core. The annual tree-ring widths of the cores were then measured with a digital positiometer (Johan Biritz GmbH).

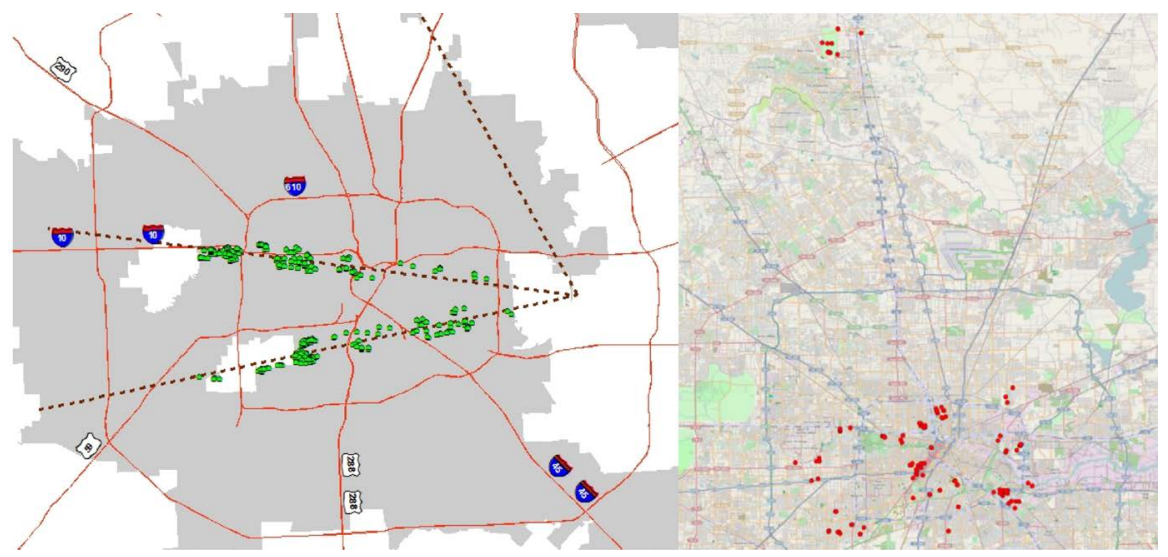

Figure 2. Selection of water oak (Q. nigra) in Houston, Texas (a) along defined transects with only a dbh of $40-60 \mathrm{~cm}$ and (b) all sampled $Q$. nigra trees in and surrounding Houston, Texas. 
For cross-dating of the time-series the software packages TSAP-Win (Rinn Tech, 2010) was used. All following analyses were carried out with $R$ (R Core Team, 2014), package dplR (Bunn et al., 2015). The tree-ring series were detrended with a double detrending process, applying modified negative exponential curves and cubic smoothing splines (20 years rigidity, 50\% wavelength cutoff, further averaged with Tukey's biweight robust mean. The autocorrelation of every series was removed using autoregressive models (maximum order of 3). All further analyses of climate-growth correlations were conducted with the resulting chronologies. From the chronologies, the age of the analyzed trees was derived. If the exact age of the tree was not clear (missing tree pith etc.), the age was back-calculated based on the undetrended average growth rate of the last ten years and the missing distance derived from $\mathrm{dbh}$ and the cumulative measured year rings of a tree. For more detailed information about the sampling preparation and measurement of core samples see Moser et al. (2016).

\subsection{Grade of Soil Sealing}

To analyze the effect of soil sealing on tree growth, data on ground imperviousness of Houston was acquired of Multi-Resolution Land Characteristics Consortium (2014) and Houston-Galveston Area Council (2014). With ArcGIS (Esri), each dataset was converted in a raster with a $30 \mathrm{~m}$ resolution with each pixel containing a value between $0-100$ to indicate the grade of soil sealing (100 as completely sealed and 0 as completely unsealed) (Xian et al., 2011). The derived values take into account both buildings and paved surfaces. Within the analyzed areas the landcover index of all raster points was sampled and related to entire number of raster points. Hereby increasing areas of $100 \mathrm{~m}, 250 \mathrm{~m}, 500 \mathrm{~m}, 1 \mathrm{~km}$, $2 \mathrm{~km}$ and $3 \mathrm{~km}$ were created around each measured tree. Then the value of soil sealing was averaged for each area and each tree. The derived value can be assumed as the "urbanity percentage" (UP) of each individual tree.

\subsection{Data Processing}

Further data analysis was also conducted with the software packages $\mathrm{R}$, version 3.3.3 (R Core Team, 2014). First, analysis of variance (ANOVA) with Tukey's HSD test was performed to identify differences between growing sites (urban, suburban, rural, forest). Using the R package lme 4 (Bates et al., 2015), linear mixed models of the following form were then developed to assess the influence of the time of age, growth (before 1960-since 1960), urbanity (urban-rural), climate (temperature-precipitation) and cardinal direction (east, north, west, south) on the annual basal area (response variable) derived by increment cores:

$$
\text { Basal } \text { area }_{i j}=\beta_{1} \times x_{1 j}+\cdots+\beta_{n} \times x_{n i j}+b_{i 1} \times z_{1 i j}+\cdots+b_{i n} \times z_{n i j}+\varepsilon_{i j},
$$

where the basal area is the response variable for the jth of $n_{i}$ observations in the ith of $\mathrm{M}$ groups or clusters, $\beta_{1}, \cdots, \beta_{n}$ are the fixed-effect coefficients, which are identical for all groups, $x_{1 i j} \cdots, X_{n i j}$ are the fixed-effect regressors for observation $j$ in group $i$; the first regressor is usually for the constant, $x_{1 i j-1}, b_{i 1}, \cdots, b_{i n}$ are the 
random-effect coefficients for group $i, Z_{1 i p} \cdots, Z_{n i j}$ are the random-effect regressors, and $\varepsilon_{i j}$ is the error for observation $j$ in group $i$.

\section{Results}

In Table 1, the tree characteristics of all analyzed water oak trees are summarized with given minimum, maximum and average measured values. Smallest trees had a dbh of $34.2 \mathrm{~cm}$, while greatest dbh was $98.0 \mathrm{~cm}$ with an average of $59.9 \mathrm{~cm}$ dbh for all trees. The average age of water oak trees was 53.1 years (16.0 years minimum and 114.0 maximum). Figure 3 displays the average undetrended increment growth, basal area increment and age-detrended growth of water oak in Houston, Texas from 1947 to 2014.

Table 1. Minimum, average and maximum dbh, increment growth (ig), tree height, age, crown base, crown radius and crown projection area (CPA) of the analyzed water oak trees (Q. nigra) in Houston.

\begin{tabular}{cccccccc}
\hline & Dbh [cm] & $\begin{array}{c}\text { ig } \\
{\left[\mathrm{mm} \cdot \mathrm{yr}^{-1}\right]}\end{array}$ & $\begin{array}{c}\text { Tree height } \\
{[\mathrm{m}]}\end{array}$ & Age [a] & $\begin{array}{c}\text { Crown } \\
\text { base [m] }\end{array}$ & $\begin{array}{c}\text { Crown } \\
\text { radius [m] }\end{array}$ & CPA [m²] \\
\hline Min & 34.2 & 0.41 & 10.0 & 16.0 & 1.2 & 3.4 & 37.3 \\
Avg & 59.9 & 4.39 & 16.1 & 53.1 & 3.8 & 7.0 & 162.7 \\
Max & 98.0 & 27.23 & 25.0 & 114.0 & 11.6 & 11.7 & 432.8 \\
\hline
\end{tabular}
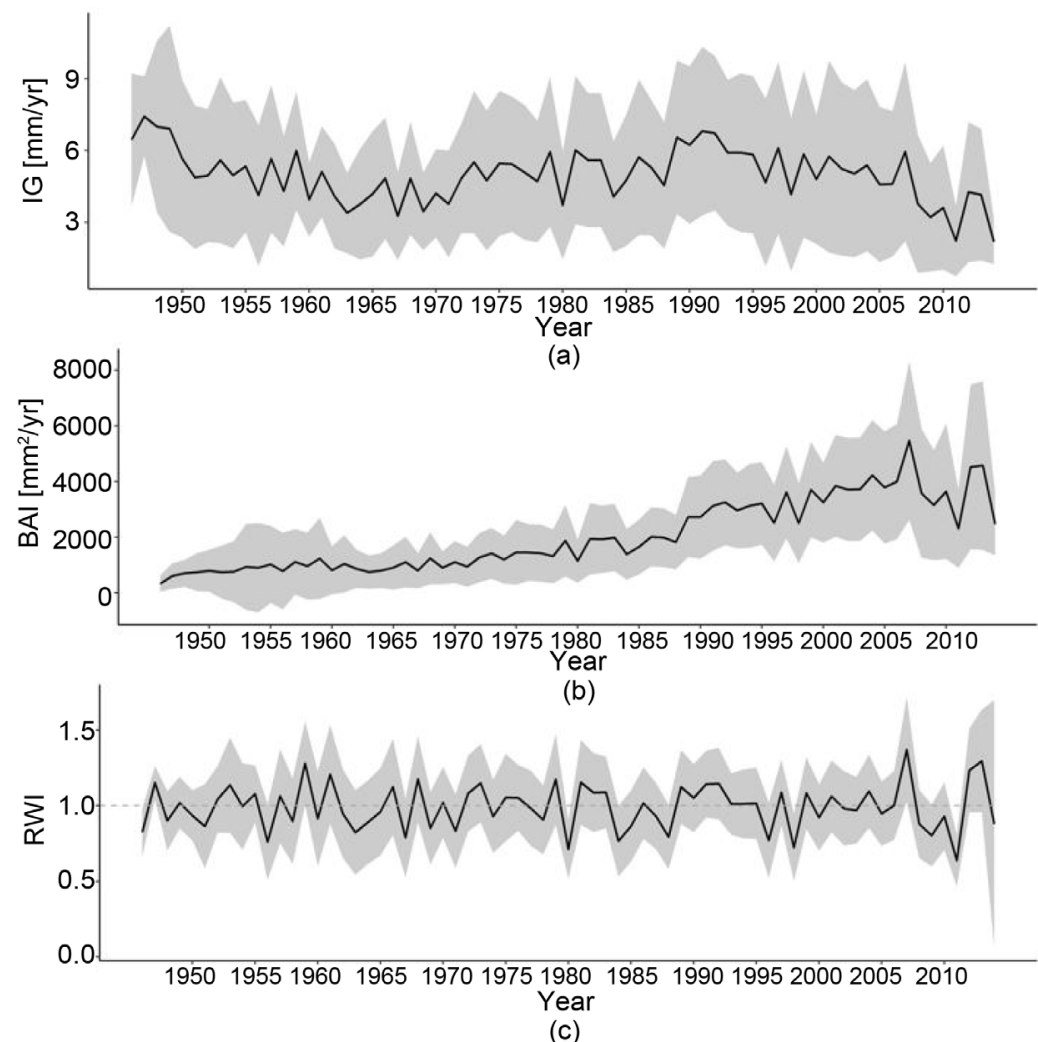

Figure 3. Growth increment (a), basal area increment (b) and detrended ring width index (c) of all sampled water oak trees ( $Q$. nigra) in Houston with according standard deviation (grey areas). 


\subsection{Long-Term Growth Trends}

Pretzsch et al. (2014) found for forest trees in Central Europe an accelerated growth, which was similar to the results of the worldwide study on urban tree growth (Figure 4 black lines). Averaged over all 10 metropolis growth of urban trees of the last fifty years (since 1960) was faster than in previous decades before 1960. Moreover, the trees in urban regions grew better than the trees in rural areas. In Houston, both trends were observed as well (Figure 4): The growth of water oak was even more enhanced than the mean growth trend of urban tree species worldwide. Since 1960, water oak showed a distinct faster growth compared to the period before 1960 (Figure 4(a)). Further, the average growth of water oak was in both periods greater than the average growth of the measured worldwide trees in cities. Regarding the growth trends of urban and rural trees, again similar patterns were found compared to the results for all metropolises. Albeit the differences between urban trees and rural trees were small, urban trees of water oak showed a slightly better growth than rural trees (Figure 4(b)).

The results of the statistical models in Figure 4 are presented in Table 2(a) and Table 2(b). As illustrated in Figure 4 and Table 2(a) and Table 2(b) age had a positive effect on growth, with increasing age the trees in Houston grew better. In particular, growth past 1960 was accelerated, while before 1960 growth of water oak was slower. Urbanity classification (urban to rural) also had a significant effect on the growth rate, with urban trees showing higher basal area growth than rural trees, however this effect was decreasing with age.

\subsection{Trends in Relation to the Growing Site}

In a next step, the growth over the past years was analyzed regarding the growing

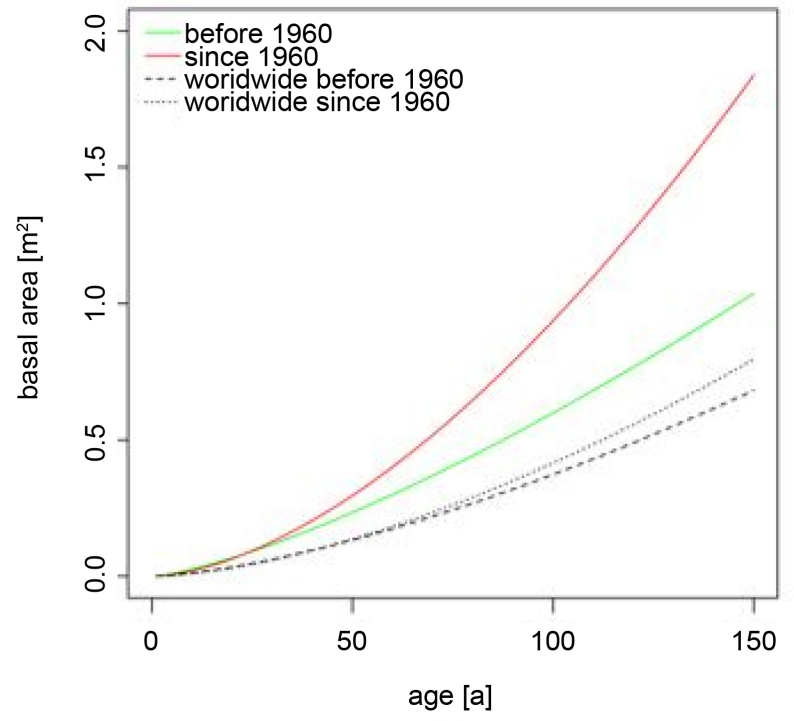

(a)

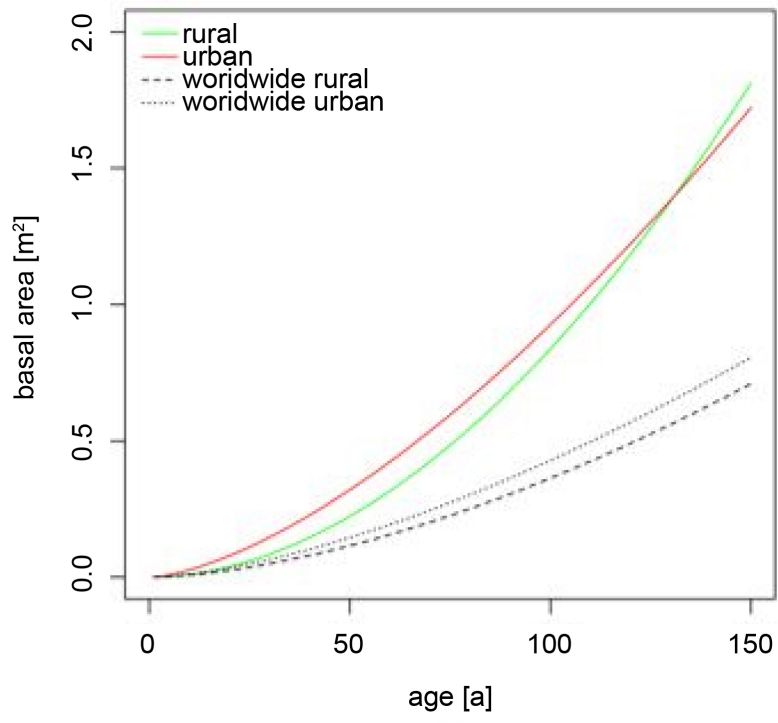

(b)

Figure 4. The size growth in terms of basal area growth of water oak (Q. nigra) in Houston and the overall urban tree growth project for (a) the period before 1960 compared to the period since 1960 and (b) urban trees compared to more rural growing trees. 
Table 2. (a) Linear mixed model on the annual basal area increment $\left(\mathrm{mm}^{2} \cdot \mathrm{yr}^{-1}\right)$ of all analyzed trees (response variable) with the individual tree code as random effect and fixed effects logarithmized age related to the factor time of growth (period before 1960 and period since 1960). (b) Linear mixed model on the annual basal area increment $\left(\mathrm{mm}^{2} \cdot \mathrm{yr}^{-1}\right)$ of all analyzed trees (response variable) with the individual tree code as random effect and fixed effects logarithmized age related to the growing site (urban and rural).

(a)

\begin{tabular}{ccc}
\hline & Value $\pm \mathrm{SE}$ & $\boldsymbol{p}$ \\
\hline Intercept & $-6.75 \pm 0.11$ & $<0.001$ \\
Age & $1.435 \pm 0.03$ & $<0.001$ \\
Time of growth & $-0.96 \pm 0.10$ & $<0.001$ \\
Age: Time of growth & $0.31 \pm 0.03$ & $<0.001$ \\
SDIntercept & 0.57 & - \\
$\varepsilon$ & 0.20 & - \\
\hline
\end{tabular}

Levels of Time of growth: 2 (Before 1960 and Since 1960), SD: Standard deviation.

(b)

\begin{tabular}{ccc}
\hline & Value \pm SE & $p$ \\
\hline Intercept & $-8.94 \pm 0.11$ & $<0.001$ \\
Age & $1.90 \pm 0.01$ & $<0.001$ \\
Urbanity & $1.82 \pm 0.13$ & $<0.001$ \\
Age: Urbanity & $-0.37 \pm 0.01$ & $<0.001$ \\
SDIntercept & 0.51 & - \\
\hline $\mathcal{E}$ & 0.19 & - \\
\hline
\end{tabular}

Levels of Urbanity: 2 (Urban and Rural), SD: Standard deviation.

site in a finer scale (urban, suburban, rural, forest) (Figure 5). An overall better growth of the urban trees can be observed, while forest trees grew the least. Rural trees and suburban trees showed intermediate growth rates. However during younger age, rural trees partly had highest growth rates though smallest basal area increment.

Further tree structures, growth and age varied significantly depending on growing location (Table 3). While increment growth was highest for urban trees, differing significantly of suburban, rural and forest trees, greatest age, crown base and tree height was found for forest trees. Crown projection area and crown radius were greatest for rural and suburban trees.

Then water oak was categorized based on growth areas regarding cardinal direction (north, east, south, west), with no clear differences between the directions (Figure 6). Basal area increment (Figure 6(b)) revealed a higher growth for trees in southern and eastern direction and least growth for water oak trees growing in northern and western direction.

The growth of the past ten years of water oaks in different cardinal directions was further tested on climate influence. Albeit a graphical illustration of tree 


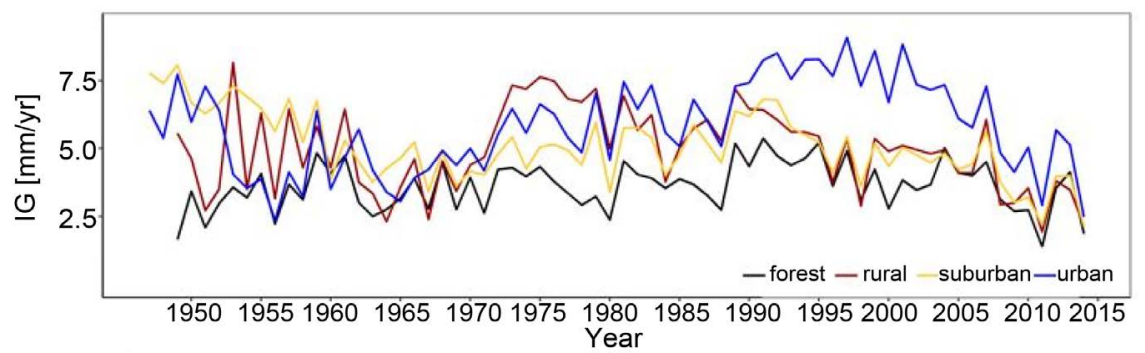

(a)

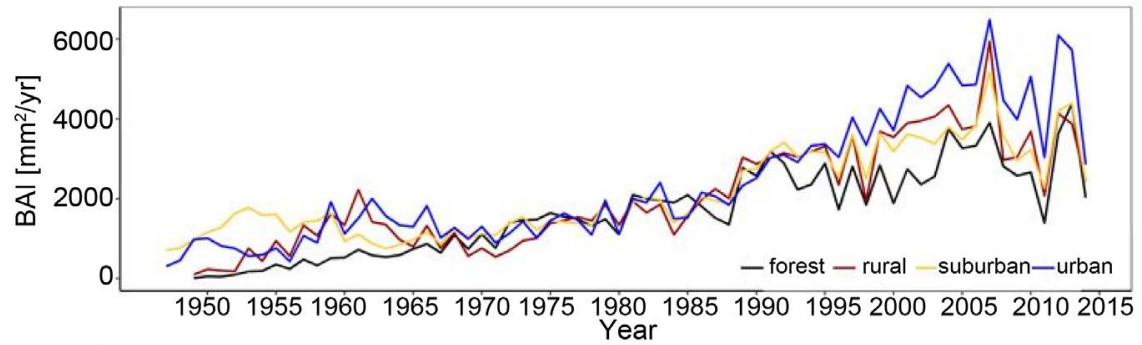

(b)

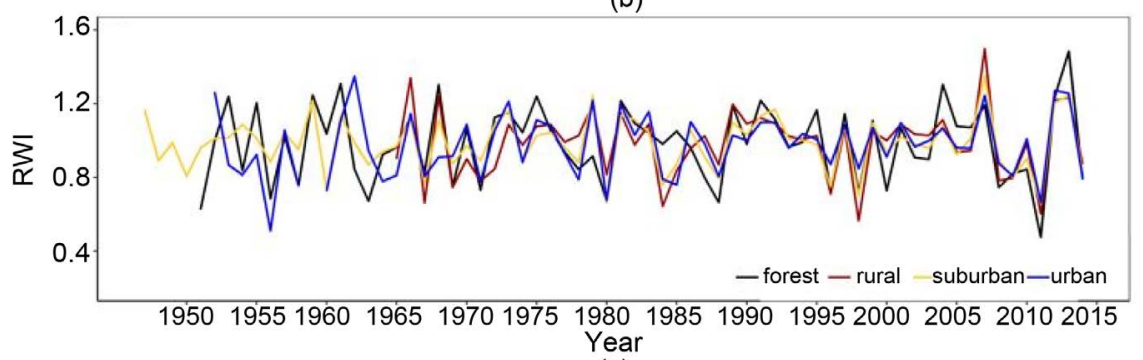

(c)

Figure 5. Growth increment (a), basal area increment (b) and ring width index RWI (c) of water oak (Q. nigra) in Houston growing at forest, rural, suburban and urban sites.

Table 3. Dbh, increment growth (ig), tree height, age, crown base, crown radius and crown projection area (cpa) of water oak trees (Q. nigra) in the four different site categories forest, rural, suburban and urban with standard deviation.

\begin{tabular}{|c|c|c|c|c|c|c|c|c|}
\hline & $\mathbf{n}$ & $\mathrm{Dbh}[\mathrm{cm}]$ & ig $[\mathrm{mm}]$ & Tree height [m] & Age [a] & Crown base $[\mathrm{m}]$ & Crown radius $[\mathrm{m}]$ & $\mathrm{CPA}\left[\mathrm{m}^{2}\right]$ \\
\hline Forest & 16 & $44.1^{\mathrm{a}} \pm 4.1$ & $4.2^{\mathrm{a}} \pm 1.9$ & $18.7^{\mathrm{a}} \pm 3.4$ & $63.1^{\mathrm{a}} \pm 23.3$ & $7.0^{\mathrm{a}} \pm 2.5$ & $6.0^{\mathrm{a}} \pm 1.0$ & $116.5^{\mathrm{a}} \pm 34.6$ \\
\hline Rural & 33 & $60.6^{\mathrm{b}} \pm 14.0$ & $5.2^{\mathrm{a}} \pm 1.2$ & $13.8^{\mathrm{b}} \pm 3.9$ & $53.0^{\mathrm{a}} \pm 13.1$ & $3.8^{\mathrm{b}} \pm 2.0$ & $7.2^{\mathrm{b}} \pm 1.6$ & $172.4^{\mathrm{b}} \pm 77.3$ \\
\hline Suburban & 92 & $62.3^{\mathrm{b}} \pm 14.2$ & $5.4^{\mathrm{a}} \pm 2.3$ & $16.1^{c} \pm 2.6$ & $56.3^{\mathrm{a}} \pm 17.8$ & $3.5^{\mathrm{b}} \pm 1.1$ & $7.2^{\mathrm{b}} \pm 1.6$ & $170.2^{\mathrm{b}} \pm 76.1$ \\
\hline Urban & 39 & $60.1^{\mathrm{b}} \pm 12.3$ & $7.3^{\mathrm{b}} \pm 2.5$ & $15.9^{c} \pm 2.4$ & $41.6^{\mathrm{b}} \pm 17.1$ & $3.3^{\mathrm{b}} \pm 1.2$ & $6.9^{\mathrm{ab}} \pm 1.2$ & $153.6^{\mathrm{ab}} \pm 54.3$ \\
\hline
\end{tabular}

Mean values in the same column differ significantly when followed by different letters (Tukey's test, $p<0.05$ ), $\mathrm{n}=$ sample size.

growth highlights a better growth of water oak trees in southern direction, a mixed model analysis revealed that there is no difference regarding cardinal directions in terms of climate influence. The growth of water oak in Houston was positively affected by the climate of Houston overall $(p<0.001)$, however no significant influence of cardinal direction was found. The climate data of northern regions (Conroe and Houston Intercontinental Airport) did not significantly affect trees growing in the northern direction as well as the climate data of southern regions (Hobby climate station) showed no correlation with the growth of the trees in southern direction. 


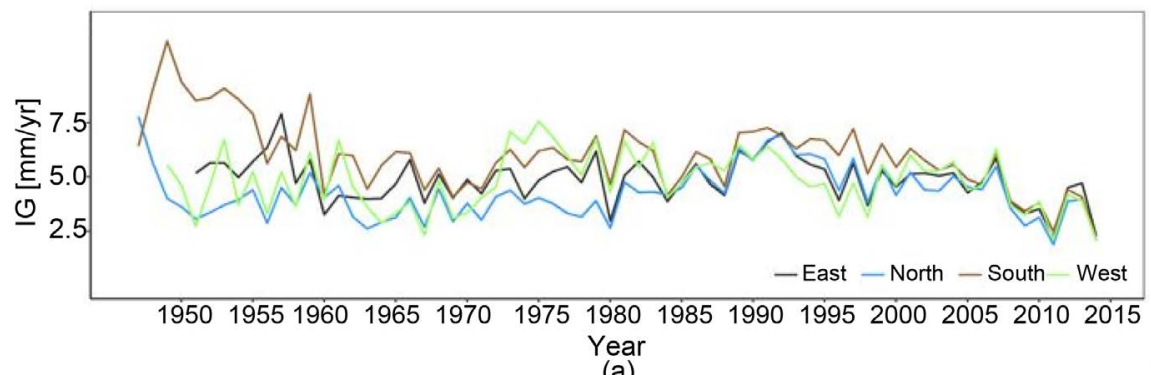

(a)
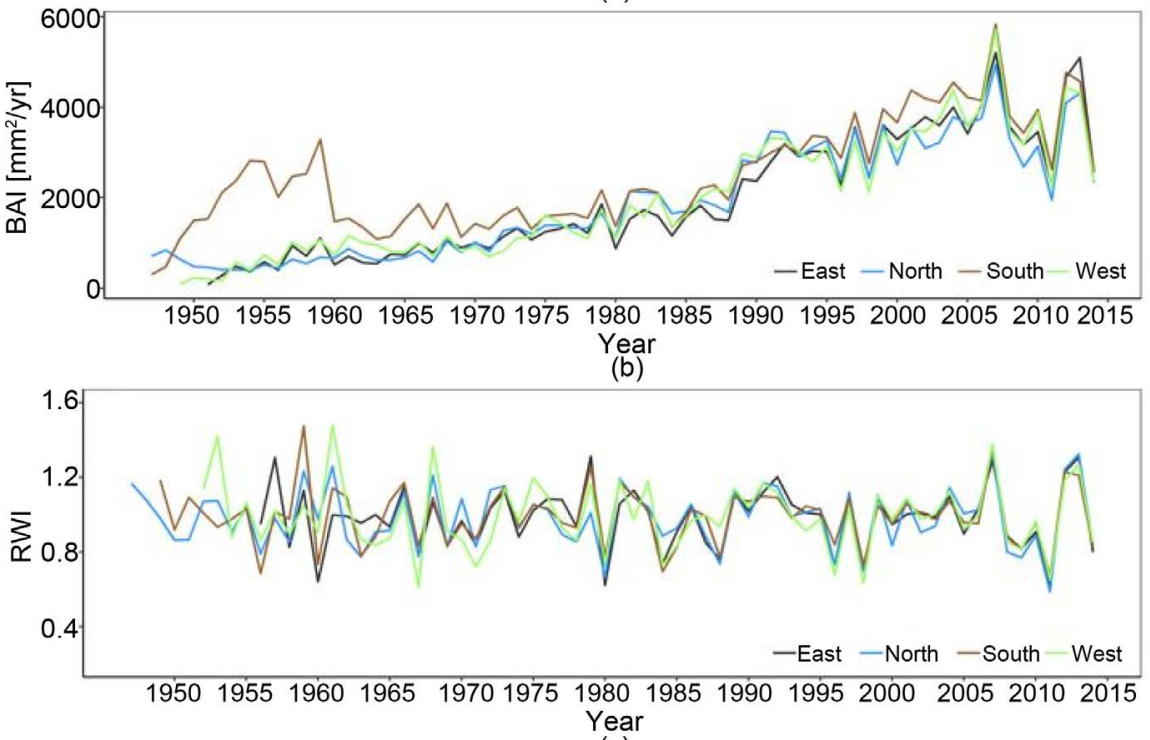

(c)

Figure 6. Growth increment (a), basal area increment (b) and ring width index RWI (c) of water oak (Q. nigra) in Houston growing in northern, eastern, southern and western direction.

\subsection{Influence of Imperviousness}

In Figure 7, a map of imperviousness of the area of Houston around the sampled trees is displayed. As examples, several trees of the city center and trees of the forest area are shown. It is obvious, that the trees in the city area have a higher value of imperviousness compared to the forest trees and more rural trees.

On average, the buffer of $100 \mathrm{~m}$ around the trees had the lowest urbanity percentages, however differences to other distances were not significant (Figure 8(a)). Further non-linear regression modelling revealed mostly minimal influence of urbanity percentages on tree growth (data not shown). Only the buffer sized $1 \mathrm{~km}, 2 \mathrm{~km}$ and $3 \mathrm{~km}$ were found to have a significant positive influence on growth $(p<0.05)$. The influence on growth did increase over time (Figure $8(b))$.

\section{Discussion and Conclusion}

\subsection{Growth of $Q$. nigra}

The overall diameter growth rate of water oak was comparatively fast with an average of $0.88 \mathrm{~mm}$ per year. Thus, water oak belongs to the category of "large-sized, short-lived, moderate to fast growth rate" (Nowak et al., 2002). 


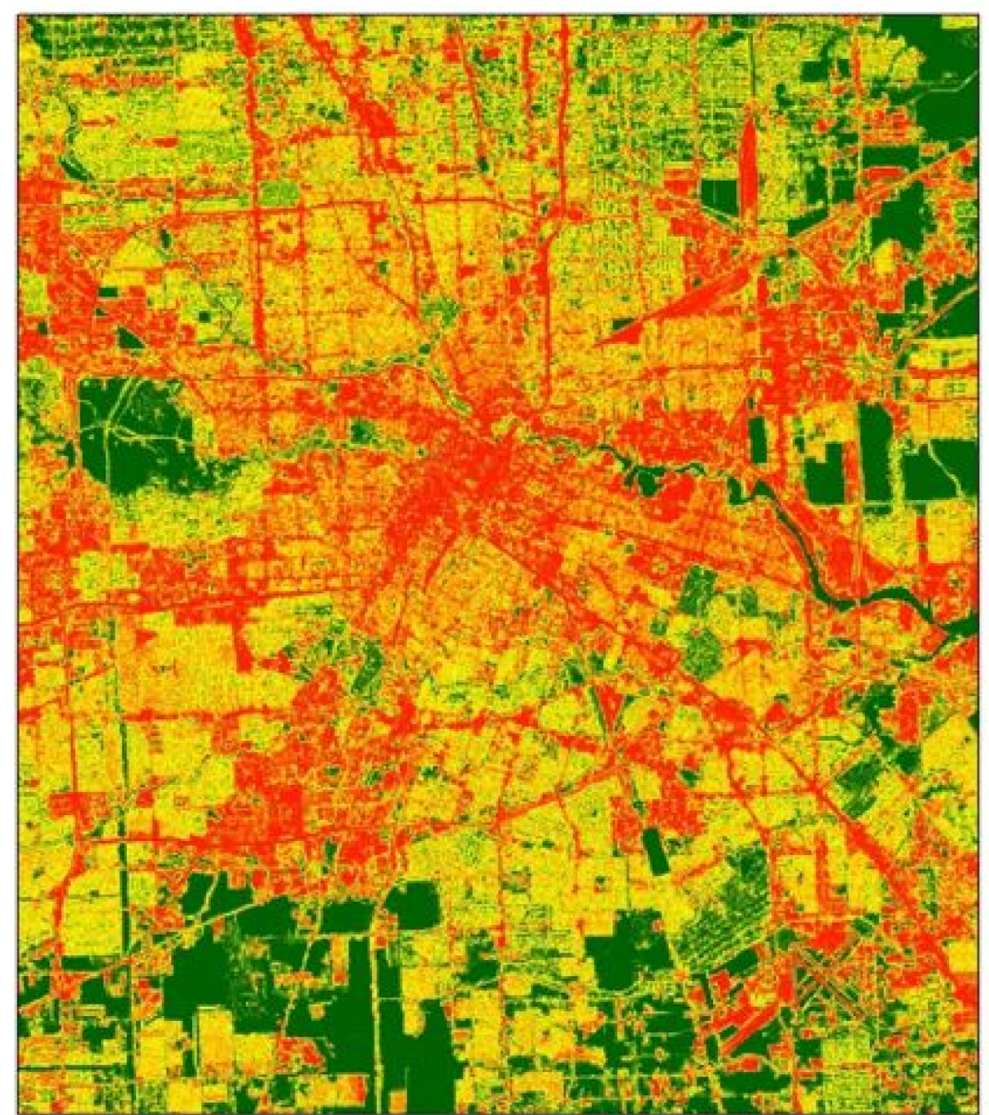

(a)

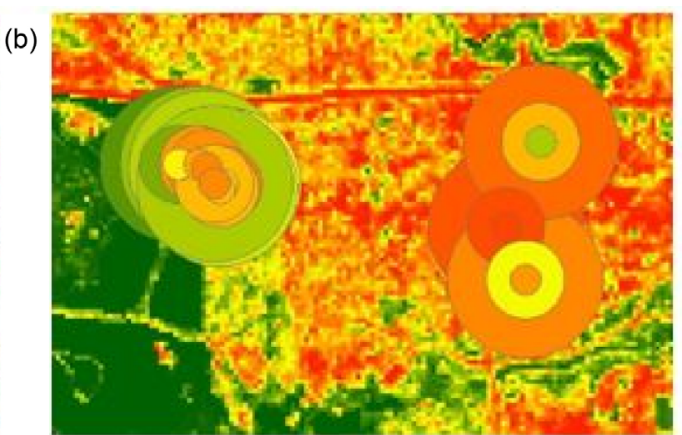

(c)

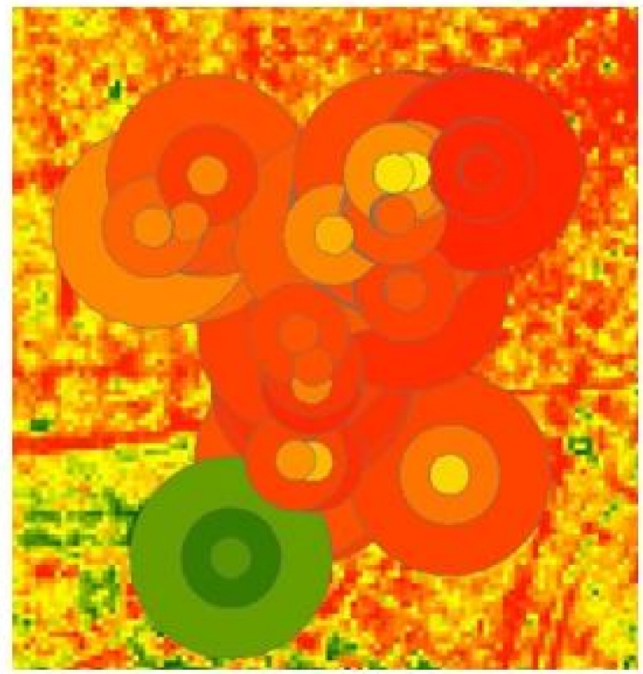

Legend

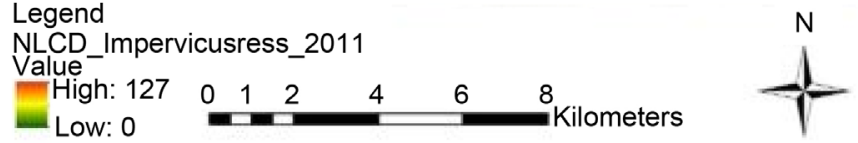

Figure 7. Grade of surface sealing of selected water oak trees (Q. nigra) overall (a), at a forest site and more suburban areas (b) and in the city center (c). Here, the 2006 NLCD imperviousness raster provides and image of the city while the circles represent different area sizes around a selection of trees (here the $100 \mathrm{~m}, 250 \mathrm{~m}$, and $500 \mathrm{~m}$ buffers are displayed. Their colors represent the average of all the impervious values underneath them.

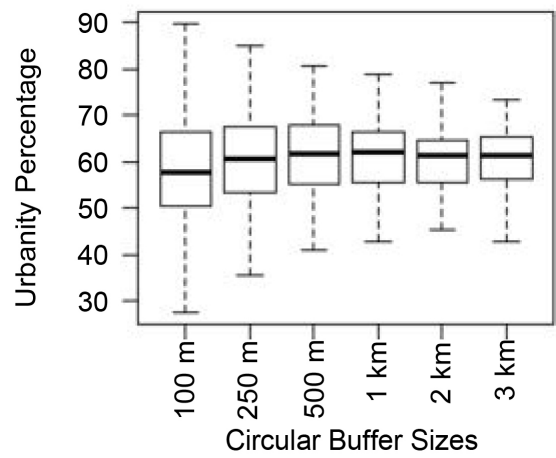

(a)

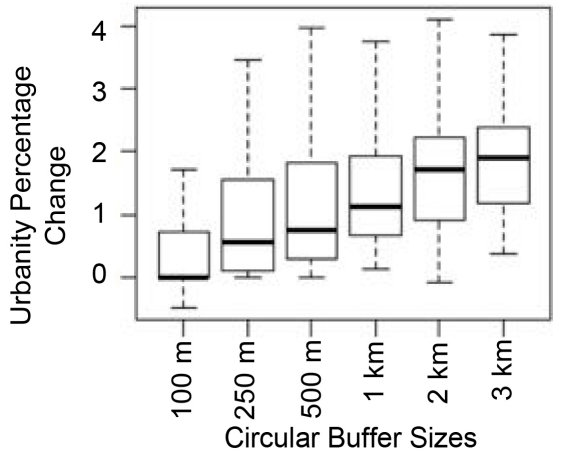

(b)

Figure 8. The urbanity percentages (grade of imperviousness) for water oak (Q. nigra) in Houston for different buffer zones for (a) 2011 and (b) the change in urbanity percentages from 2001 to 2011. Significant results $(p<0.05)$ were found for buffer sizes greater than $1 \mathrm{~km}$. 
With an average age of 53 years, the urban water oak trees in Houston exceed the average ages of street trees stated by Moll (1989), Skiera \& Moll (1992) and Roman \& Scatena (2011). Significant differences in growth were found for the different sampling sites forest, rural, suburban and urban, with urban trees showing highest average growth rate though youngest age. Forest trees however had the highest age, height and crown base. These findings can be explained with a greater tree density and higher light competition in forest stands whereas in cities trees are mostly planted in rows along streets or as stand-alone trees at public squares. Therefore urban trees often achieve greater tree dimensions such as crown radius and crown projection area than forest trees (Hasenauer, 1997; Pretzsch, 2014). However, the differences in tree sizes were also biased by a younger age of urban trees compared to rural, suburban and forest trees.

\subsection{Long-Term Growth Trends}

The higher growth rate of urban trees compared to rural trees was also observed for the overall worldwide project (Pretzsch et al., 2015a; Pretzsch et al., 2017) as well as for all climate zones. The growth rate of water oak was double as high as the average growth of all urban trees worldwide. Moreover, the short-lived character of water oak can be seen regarding the comparison of urban and rural trees: While urban trees had a higher growth rate until high age, a decline in growth was found for older urban trees. Rural trees had a high growth rate at high age too, passing the growth of urban trees of the same age. With better conditions regarding water availability, radiation and pollution immission, rural trees can outlive urban trees on the long-run. In total, an accelerated growth is similar to the growth trend for all trees in the Metropolis project.

Analogous findings about growth trends in forests worldwide (see for example Kauppi et al. (2014), Pretzsch et al. (2014) and Fang et al. (2014)) raise the question how urban trees and forests respond to changing environmental conditions. The worldwide study on 10 urban tree species integrating boreal, temperate, Mediterranean, and subtropical climate conditions revealed that across all climate zones, urban tree growth has significantly enhanced during the past decades, possibly due to global climate change leading to higher temperatures, air pollution, $\mathrm{CO}_{2}$ concentrations and prolonged growing seasons (Chmielewski \& Rötzer, 2001; Churkina et al., 2010; IPCC, 2014). On average, trees in the city centers grew significantly quicker than the rural trees. The recent decades' enhanced size growth results in increased carbon sequestration, accelerated spatial above and below ground expansion, and earlier provision of many ecosystem services. However, it also translates to more rapid aging, possibly indicating a need for earlier replanting. In order to sustain green urban infrastructure, planning and management should adapt to these changed dynamics. Interestingly the increase in growth is contradictory to findings by Gilman \& Watson (1994) that water oak reduces growths in a warm and dry subtropical climate. Warmer and drier conditions together with high pollution immission predicted for the 
near future will not necessarily lead to suppressed water oak growth as seen in this study, particularly if vapor pressure deficit increases with increasing temperature (Friedrichs et al., 2009). Water oak's surprising drought resistance could be important for future urban tree plantings in view of climate change (Zeppel et al., 2011).

\subsection{Influence of Site Conditions on Tree Growth}

While the influence of the growing site urban vs. rural proved to be of significant influence on tree growth of water oak, the growing direction (north, east, south, west) had no marked effect on growth. Since the climate of Houston varies depending on the direction with the Gulf of Mexico in southeast and flat areas with forests in the north, the influence of temperature and precipitation of the north (Conroe, Houston Intercontinental Airport) and the southern region (Hobby Airport) was related with stem diameter growth. However, no significant influence was found in relation to the growing direction. The overall climate of Houston influenced tree growth positively, which is in line with the main finding of a positive growth trend of urban trees in Houston. The warmer city centers along with a prolonged growing season and more nutrient inputs had an overall positive influence on growth regardless of the direction and other influences like higher humidity by the sea.

Moreover, the grade of surface sealing on tree growth was tested, with only minor influence on tree growth. Close to the tree, the imperviousness grade was smallest due to planting pits and the higher grade of impervious areas around forest trees. In higher distance of 1,2 and $3 \mathrm{~km}$ a significant positive correlation with increasing impact over time was found. The grade of urbanity increased as well over time, with a higher grade of urbanity positively influencing growth. This is in line with the findings of better growth in urban areas.

\subsection{Conclusion}

This study illustrated how the growth patterns of urban trees-water oak, Q. nigra in Houston, Texas-were influenced by site conditions like grade of urbanity, climate, and time. Best growth was found in urban areas and growth accelerated over time, which was surprising since water oak is a species typically growing on more moist sites. Its performance under drought conditions makes this species suitable for future conditions, however growth under even drier and warmer conditions needs to be studied in detail for future planting suggestions. The findings regarding water oak are in line with the worldwide project on urban tree growth across climate regions: There is a change in urban tree growth, probably caused by climate change and immissions leading to enhanced tree growth in city centers. Due to the warmer city climate, extended growing seasons and high pollution loads, water oaks in Houston, Texas were able to perform better under urban climate compared to more rural sites. However, if this trend will continue under more harsh growing conditions is doubtful. So far, the 
positive effects of the urban environment (extended growing season etc.) still seem to have the upper hand over the negative effects (air pollution etc.). Even today, the accelerated growth might lead to faster ageing and tree death, reducing the services and benefits of urban trees especially older trees are able to provide, which might be detrimental for the living conditions in cities like Houston. Further studies on the effects of climate change on the growth and services of urban trees are necessary to ensure low-cost, healthy and beneficial urban green for a comfortable climate in cities.

\section{Acknowledgements}

Thanks to the AUDI Environmental Foundation for funding this study (project 5101954: "Reaktionskinetik von Bäumenunter Klimaveränderungen"- "Reaction kinetics of trees under climate change"). All contributors thank the municipal authority of Houston/Texas for supporting the search for the trees and the allowance of measuring and coring the trees.

\section{References}

Akbari, H., Pomerantz, M., \& Taha, H. (2001). Cool Surfaces and Shade Trees to Reduce Energy Use and Improve Air Quality in Urban Areas. Solar Energy, 70, 295-310. https://doi.org/10.1016/S0038-092X(00)00089-X

Bartens, J., Day, S. D., Harris, J. R., Dove, E. E., \& Wynn, T. M. (2008). Can Urban Tree Roots Improve Infiltration through Compacted Subsoils for Stormwater Management? Journal of Environmental Quality, 37, 2048-2057. https://doi.org/10.2134/jeq2008.0117

Bassuk, N., Deanna, F. C., Marranca, B. Z., \& Barb, N. (2009). Recommended Urban Trees: Site Assessment and Tree Selection for Stress Tolerance. Ithaca, New York: Urban Horticulture Institution, Cornell University.

Bates, D., Maechler, M., Bolker, B., \& Walker, S. (2015). Linear Mixed-Effects Models Using "Eigen" and S4. R Package Version 1.1-9.

Böll, S., Schönfeld, P., Körber, K., \& Herrmann, J. V. (2014). Stadtbäume Unter Stress. Projekt "Stadtgrün 2021" untersucht Stadtbäume im Zeichen des Klimawandels. (City Trees under Stress. Project "City Green 2021" Analyses Urban Trees in View of Climate Change). LWF Aktuell, 98, 4-8.

Bolund, P., \& Hunhammar, S. (1999). Ecosystem Services in Urban Areas. Ecological Economics, 29, 293-301. https://doi.org/10.1016/S0921-8009(99)00013-0

Bühler, O., Kristoffersen, P., \& Larsen, S. U. (2007). Growth of Street Trees in Copenhagen with Emphasis on the Effect of Different Establishment Concepts. Arboriculture \& Urban Forestry, 5, 330-337.

Bunn, A., Korpela, M., Biondi, F., Campelo, F., Mérian, P., Qeadan, F., Zang, C., Buras, A., Cecile, J., Mudelsee, M., \& Schulz, M. (2015). Package “dplR”. Dendrochronology Program Library in R, Version 1.6.3 ed.

Cekstere, G., Nikodemus, O., \& Osvalde, A. (2008). Toxic Impact of the De-Icing Material to Street Greenery in Riga, Latvia. Urban for Urban Greening, 7, 207-217. https://doi.org/10.1016/j.ufug.2008.02.004

Chmielewski, F. M., \& Rötzer, T. (2001). Response of Tree Phenology to Climate Change across Europe. Agricultural and Forest Meteorology, 108, 101-112. https://doi.org/10.1016/S0168-1923(01)00233-7 
Churkina, G., Zaehle, S., Hughes, J., Viovy, N., Chen, Y., Jung, M., Heumann, B. W., Ramankutty, N., Heimann, M., \& Jones, C. (2010). Interactions between Nitrogen Deposition, Land Cover Conversion, and Climate Change Determine the Contemporary Carbon Balance of Europe. Biogeosciences, 7, 2749-2764.

https://doi.org/10.5194/bg-7-2749-2010

City of London (2014). City of London Urban Forest Strategy. Enhancing the Forest City.

Climate Central (2015). Across U.S., Heaviest Downpours on the Rise.

Coburn, J. (2009). Cities, Climate Change and Urban Heat Island Mitigation: Localising Global Environmental Science. Urban Studies, 46, 413-427. https://doi.org/10.1177/0042098008099361

Cregg, B. M., \& Dix, M. E. (2001). Tree Moisture Stress and Insect Damage in Urban Areas in Relation to Heat Island Effects. Journal of Arboriculture, 27, 8-17.

Dimoudi, A., \& Nikolopoulou, M. (2003). Vegetation in the Urban Environment: Microclimatic Analysis and Benefits. Energy Build, 35, 69-76.

Dobbs, C., Kendal, D., \& Nitschke, C. R. (2014). Multiple Ecosystem Services and Disservices of the Urban Forest Establishing Their Connections with Landscape Structure and Sociodemographics. Ecological Indicators, 43, 44-55.

Escobedo, F. J., \& Nowak, D. J. (2009). Spatial Heterogeneity and Air Pollution Removal by an Urban Forest. Landscape and Urban Planning, 90, 102-110.

Fang, J., Kato, T., Guo, Z., Yang, Y., Hu, H., Shen, H., Zhao, X., Kisimoto-Mo, A. W., Tang, Y., \& Houghton, R. A. (2014). Evidence for Environmentally Enhanced Forest Growth. PNAS, 111, 9527-9532. https://doi.org/10.1073/pnas.1402333111

Friedrichs, D. A., Buntgen, U., Frank, D. C., Esper, J., Neuwirth, B., \& Loffler, J. (2009). Complex Climate Controls on 20th Century Oak Growth in Central-West Germany. Tree Physiology, 29, 39-51. https://doi.org/10.1093/treephys/tpn003

Gilman, E. F., \& Watson, D. G. (1994). Quercus nigra (Water Oak) (Vol. Fact Sheet ST-553). Environmental Horticulture Department \& Florida Cooperative Extension Service \& Institute of Food and Agricultural Sciences \& University of Florida.

Gómez-Baggethun, E., \& Barton, D. N. (2013). Classifying and Valuing Ecosystem Services for Urban Planning. Ecological Economics, 86, 235-245.

Gregory, J. H., Dukes, M. D., Jones, P. H., \& Miller, G. L. (2006). Effect of Urban Soil Compaction on Infiltration Rate. Journal of Soil and Water Conservation, 61, 117-124.

Hasenauer, H. (1997). Dimensional Relationship of Open-Grown Trees in Austria. Forest Ecology and Management, 96, 197-206.

Houston-Galveston Area Council (2014). GIS Datasets. http://www.h-gac.com/rds/gis-data/gis-datasets.aspx

IPCC (2013). Climate Change 2013: The Physical Science Basis. IPCC Working Group I Contribution to AR5.

IPCC (2014). Synthesis Report, International Panel on Climate Change. Cambridge Univ Press.

Kauppi, P. E., Posch, M., \& Pirinen, P. (2014). Large Impacts of Climate Warming on Growth of Boreal Forest since 1960. PLoS ONE, 9, e111340.

Leistikow, K. U. (2013). The Woodbook: The Complete Plates. Köln: TASCHEN Verlag.

Moll, C. W. (1989). The State of Our Urban Forest. Am Forests, 95, 61-64.

Morgenroth, J., \& Buchan, G. D. (2009). Soil Moisture and Aeration beneath Pervious and Impervious Pavements. Arboriculture \& Urban Forestry, 35, 135-141.

Moser, A., Rötzer, T., Pauleit, S., \& Pretzsch, H. (2016). The Urban Environment Can 
Modify Drought Stress of Small-Leaved Lime (Tilia cordata Mill.) and Black Locust (Robinia pseudoacacia L.). Forests, 7, 71. https://doi.org/10.3390/f7030071

Mueller, R. C., Scudder, C. M., Porter, M. E., Trotter, I. R. T., Gehring, C. A., \& Whitham, T. G. (2005). Differential Tree Mortality in Response to Severe Drought: Evidence for Long-Term Vegetation Shifts. Journal of Ecology, 93, 1085-1093. https://doi.org/10.1111/j.1365-2745.2005.01042.x

Multi-Resolution Land Characteristics Consortium (2014). National Land Cover Database 2001, 2006, and 2011 (NLCD2011). U.S. Department for the Interior, U.S. Geological Survey. http://www.mrlc.gov

NCDC, NOAA (2014). National Climatic Data Center.

Nowak, D. J., Stevens, J. C., Sisinni, S. M., \& Luley, C. J. (2002). Effects of Urban Tree Management and Species Selection on Atmospheric Carbon Dioxide. Journal of Arboriculture, $28,113-122$.

Oke, T. (1987). Boundary Layer Climate. New York, NY: University Paperbacks.

Petersen, A., \& Eckstein, D. (1988). Roadside Trees in Hamburg-Their Present Situation of Environmental Stress and Their Future Chance for Recovery. Journal of Arboriculture, 12, 109-117. https://doi.org/10.1080/03071375.1988.9756382

Pretzsch, H. (2014). Canopy Space Filling and Tree Crown Morphology in Mixed-Species Stands Compared with Monocultures. Forest Ecology and Management, 327, 251-264.

Pretzsch, H., Biber, P., Schütze, G., Uhl, E., \& Rötzer, T. (2014). Forest Stand Growth Dynamics in Central Europe Have Accelerated since 1870. Nature Communications, 5, 4967. https://doi.org/10.1038/ncomms5967

Pretzsch, H., Biber, P., Uhl, E., Dahlhausen, J., Rötzer, T., Caldentey, J., Koike, T., van Con, T., Chavanne, A., Seifert, T., du Toit, B., Farnden, C., \& Pauleit, S. (2015a). Crown Size and Growing Space Requirement of Common Tree Species in Urban Centres, Parks, and Forests. Urban for Urban Greening, 14, 466-479.

Pretzsch, H., Rötzer, T., Pauleit, S., \& Moser, A. (2015b). Stadtbäume im Klimawandel Wuchsverhalten, Umweltleistungen und Perspektiven. Schlussbericht mit Leitfaden. [Urban Trees and Climate Change-Growth, Ecosystem Services and Perspectives.]

Pretzsch, H., Biber, P., Uhl, E., Dahlhausen, J., Schütze, G., Perkins, D., Rötzer, T., Caldentey, J., Koike, T., van Con, T., Chavanne, A., du Toit, B., Foster, K., \& Lefer, B. (2017). Climate Change Accelerates Growth of Urban Trees in Metropolises Worldwide. Science Advances, Manuscript Submitted for Publication.

R Core Team (2014). R: A Language and Environment for Statistical Computing. Vienna: $\mathrm{R}$ Foundation for Statistical Computing.

Rahman, M. A., Moser, A., Rötzer, T., \& Pauleit, S. (2017). Microclimatic Differences and Their Influence on Transpirational Cooling of Tilia cordata in Two Contrasting Street Canyons in Munich, Germany. Agricultural and Forest Meteorology, 232, 443-456.

Rahman, M. A., Stringer, P., \& Ennos, A. R. (2013). Effect of Pit Design and Soil Composition on Performance of Pyrus calleryana Street Trees in the Establishment Period. Arboriculture \& Urban Forestry, 39, 256-266.

Raupp, M. J., Cumming, A. B., \& Raupp, E. C. (2006). Street Tree Diversity in Eastern North America and Its Potential for Tree Loss to Exotic Borers. Arboriculture \& Urban Forestry, 32, 297-304.

Richards, N. A. (1979). Modeling Survival and Consequent Replacement Needs of a Street Tree Population. Journal of Arboriculture, 5, 251-255.

Rinn Tech (2010). TSAP-Win: Time Series Analysis and Presentation for Dendrochronology and Related Applications (Version 0.55 ed.). Heidelberg. 
Roman, L. A., \& Scatena, F. N. (2011). Street Tree Survival Rates: Meta-Analysis of Previous Studies and Application to a Field Survey in Philadelphia, PA, USA. Urban for Urban Greening, 10, 269-274.

Santamouris, M., Synnefa, A., \& Karlessi, T. (2011). Using Advanced Cool Materials in the Urban Built Environment to Mitigate Heat Islands and Improve Thermal Comfort Conditions. Solar Energy, 85, 3085-3102.

Shafer, M., Ojima, D., Antle, J. M., Kluck, D., McPherson, R. A., Petersen, S., Scanlon, B., \& Sherman, K. (2014). Ch. 19: Great Plains. Climate Change Impacts in the United States: The Third National Climate Assessment (pp. 441-461). U.S. Global Change Research Program.

Sjöman, H., Hirons, A. D., \& Bassuk, N. L. (2015). Urban Forest Resilience through Tree Selection-Variation in Drought Tolerance in Acer. Urban for Urban Greening, 14, 858-865.

Sjöman, H., Östberg, J., \& Bühler, O. (2012). Diversity and Distribution of the Urban Tree Population in Ten Major Nordic Cities. Urban for Urban Greening, 11, 31-39.

Skiera, B., \& Moll, G. (1992). The Sad State of City Trees. Am Forests, 61-64.

Soares, A. L., Rego, F. C., McPherson, E. G., Simpson, J. R., Peper, P. J., \& Xiao, Q. (2011). Benefits and Costs of Street Trees in Lisbon, Portugal. Urban for Urban Greening, 10, 69-78.

Tan, J., Zheng, Y., Tang, X., Guo, C., Li, L., Song, G., Zhen, X., Yuan, D., Kalkstein, A. J., Li, F., \& Chen, H. (2010). The Urban Heat Island and Its Impact on Heat Waves and Human Health in Shanghai. International Journal of Biometeorology, 54, 75-84. https://doi.org/10.1007/s00484-009-0256-x

Tubby, K. V., \& Webber, J. F. (2010). Pests and Diseases Threatening Urban Trees under a Changing Climate. Forestry, 83, 451-459. https://doi.org/10.1093/forestry/cpq027

Tyrväinen, L., Pauleit, S., Seeland, K., \& Vries, S. (2005). Benefits and Uses of Urban Forests and Trees. In C. Konijnendijk, K. Nilsson, T. Randrup, \& J. Schipperijn (Eds.), Urban Forests and Trees: A Reference Book (pp. 81-114). Berlin, Heidelberg: Springer. https://doi.org/10.1007/3-540-27684-X_5

Wang, R. (2014). 87 Cities, 4 Scenarios and 1 Really Hot Future.

Xian, G., Homer, C., Dewitz, J., Fry, J., Hossain, N., \& Wickham, J. (2011). Change of Impervious Surface Area between 2001 and 2006 in the Conterminous United States. Photogrammetric Engineering and Remote Sensing, 77, 758-762.

Zeppel, M. J., Adams, H. D., \& Anderegg, W. R. (2011). Mechanistic Causes of Tree Drought Mortality: Recent Results, Unresolved Questions and Future Research Needs. The New Phytologist, 192, 800-803. https://doi.org/10.1111/j.1469-8137.2011.03960.x 